\title{
STRATEGY AND TACTICS IN LINGUISTIC PARADIGM
}

\section{Olha Makiedonova ${ }^{1}$}

\section{DOI: https://doi.org/10.30525/978-9934-588-11-2_44}

The peculiarity of the communicative-pragmatic approach to advertising discourse should be considered an analysis of strategies and tactics used by the compilers of advertising messages. Modern linguistics borrowed the terms «strategy» and «tactics» from the theory of military planning, in which strategy is defined as the art of conducting a war or a large-scale operation in general, and tactics - an integral part of the military art, covering the theory and practice of conducting specific operations [6]. The ultimate goal of any advertising messages is «aggressive», the advertiser organizes the perception of the message so as to capture the attention of the addressee and gain the sympathy of his ideas. By analogy, we can say that advertising (speech) activities are organized strategically by copyrights.

There is no coincidence that the term «strategy» has gained a statement and numerous interpretations in the scientific linguistic literature. The strategy is interpreted as:

- a plan for the optimal implementation of the communicative intention, which determines the combination of speech means [9, p. 130];

- a sequence of speech actions organized according to the goals of communicative interaction [8, p. 172];

- peculiar planning of the process of speech communication, depending on the specific conditions of communication and personalities of communicants $[10$, p. 54];

In our opinion, the most relevant for the English advertising discourse is the interpretation of a communicative strategy as a complex of speech actions aimed at achieving the overall communicative purpose of the speaker. Based on this definition, we have come to the conclusion that the strategy is the basic notion of communicative-pragmatic analysis of the advertising discourse.

Some scholars define a more specific language term - «speech behavior strategy», «speech strategy», «communication strategy», «discursive strategy», «manipulative strategy». Communicative strategies are explored by scientists from different perspectives, focusing on various aspects. In the philological literature the following approaches to the analysis of communicative strategies can be distinguished:

- linguistic and stylistic, according to which the strategy is considered as «content element of the text», a creative implementation of the plan for constructing speech behavior. In the center of attention are author's strategies for creating the text, textual characteristics of the strategies, compositional structure, stylistic organization [11, p. 199].

- linguistic and pragmatic, according to which the strategy refers to a complex of speech actions, aimed at achieving a communicative goal, or the method of structuring speech behavior in accordance with the communicative purpose of the

${ }^{1}$ Zaporizhzhia National University, Ukraine 
participant in communication. From this position, the strategy serves as a kind of super-task of speech and is considered through the prism of the basic concepts of linguistic pragmatics - a communicative goal, an intention and an act [3, p. 54].

- psycholinguistic, according to which the strategy is defined as the exchange of intentional wishes of the interlocutors, which contributes to the emergence of the psychological basis for speech influence, as a way of organizing speech behaviour in accordance with the plan, intention of the communicant, as well as the implementation of this plan by influencing the intellectual, volitional, emotional sphere of the addressee [1, p. 88].

- sociolinguistic, according to which the research of strategies is to determine the linguistic and socio-cultural knowledge necessity for communication, depending on the cultural, subcultural, situational specificity of interpretation [12, p. 13]. In our opinion, from this position the nature of speech communication is influenced by social factors, and therefore the social status of communicator acts as an important criterion for the selection and implementation of the strategy.

- cognitive, according to which the strategy is understood as a cognitive processing of discourse, which results in a mental conception or as a "cognitive process in which the speaker correlates its communicative purpose with a concrete language expression, comprehends the situation through interpretive schemes that promote the development of alternative ways of doing things and achieving goals» $[4$, p. 192]. From the standpoint of this approach, the strategy can be interpreted as a certain mental operation associated with processes of generation and perception of the discourse.

Despite the diversity of aspects of the research of communicative strategies, all of them point to the presence of teleology, the conditionality of the communicative goals of the participants in communication. For our recearch, we have defined the basic definition of communicative strategies from the standpoint of linguistic pragmatics, the core of which is the theory of speech acts, and the basic notion is a communicative act characterized by purposefulness, intentionality, addressability, and the presence of a communicative purpose.

The interpretation of a communicative strategy through the prism of linguistic stylistic (as a stylistic implementation of the plan for constructing the addressee's speech behaviour) and cognitive (as involving cognitive processes for correcting the picture of the world of the addressee by the addresser, which is necessary in the conditions of advertising communication) is also relevant.

At the same time, it is advisable to combine the psycho- and sociolinguistic aspects of the strategy, because an advertising message cannot be explored outside of the society and without taking into account psychological factors.

Taking into account all aspects of communicative strategies, we define this concept in linguistic coverage: the communicative strategy of the advertising discourse is a general line of the advertising message, in which linguistic and paralingual means are aimed at achieving a pragmatic goal.

There are different definitions of «communicative tactics». Tactics are defined as a separate tool for implementing a common strategy [5, p. 45-46], a speech action that 
corresponds to a certain stage of the implementation of a communicative strategy, a system of actions that ensures the effective implementation of the strategy [3, p. 110], a set of local rhetorical techniques and behavioral lines that correlate with the local goals of interaction [4, p. 116].

The tactics are also understood as the communicative steps that contribute to solving the strategic task under the control of the appropriate strategy. Communicative steps are represented by a set of speech actions used to implement one or another strategy [7, p. 8]. We consider the most relevant definition of communicative tactics as a concrete line of advertising interaction, a set of practical steps in the form of linguistic and paralinguistic means that ensure the effective implementation of the chosen strategy.

It should be noted that in modern linguistics there is a problem of the differentiation of communicative strategy and tactics, since the same medium can serve both strategy and tactics of speech behaviour [3, p. 22]. The division of communicative strategy and tactics is proposed through opposition - theory / practice, according to which the communicative strategy is a set of pre-planned theoretical steps that are realized in the process of a communicative act and aimed at achieving a communicative goal. Tactics is understood as the set of practical steps in the process of speech interaction [2, p. 11]. We adhere to the point of view that communicative strategy and tactics relate as a general phenomenon to a partial, communicative tactics acts as an instrument for implementing a particular communicative strategy.

\section{References:}

1. Borysova, Y. N. (1999). Kateghoryja cely y aspekty tekstovogho analyza [Category of objectives and aspects of text analysis]. Speech Genres Journal, vol. 1, no. 2, pp. 79-94. (in Russian)

2. Kljuev, E. V. (2002). Rechevaja kommunykacyja [Speech communication]. Moscow: Rypol Klassyk. (in Russian)

3. Yssers, O. S. (2008). Kommunykatyvnнe strateghyy y taktyky russkoj rechy [Communicative strategies and tactics of the Russian language]. Moscow: LKY. (in Russian)

4. Makarov, M. L. (2003). Osnovy teoryy dyskursa [Fundamentals of discourse theory]. Moscow : YTDGhK «Ghnozys». (in Russian)

5. Chernjavskaja, V. E. (2006). Dyskurs vlasty y vlastj dyskursa : problemy rechovogho vozdejstvyja [Discourse of power and power of discourse: problems of speech influence]. Moscow: Flynta : Nauka. (in Russian)

6. A Military Encyclopedia Electronic Resource. Retrieved from http://www.wikiwand.com/ en/Strategy, http://www.wikiwand.com/en/Tactic

7. Coleman, S., Ross, K. (2003). The Media and The Public. 'Them' and 'Us' in Media Discourse. Wiley-Blackwell, pp. 7-12.

8. Cook, G. (2006). The Discourse of Advertising. London and New York: Routledge.

9. Drewniany, B., Jewler, A., (2010). Creative Strategy in Advertising. Wadsworth Publising.

10. Dijk, T. A. van, Kintsch, W. (1983). Strategies of Discourse Comprehension. New York.

11. Gumperz, J. J. (1982). Discourse strategies. Cambridge : Cambridge University Press.

12. Kress, G. R. (2002). Multimodal Discourse : The Modes and Media of Contemporary Communication. London : Edward Arnold. 